\title{
……

\section{Pengaruh Pengembangan Kawasan Wisata Geopark Merangin Terhadap Kesejahteraan Masyarakat Desa Air Batu}

\author{
Indra Putra Dinata', Mussadun² \\ Diterima : Juli 2015 \\ Disetujui : 7 September 2015
}

\begin{abstract}
Geopark Merangin has enormous tourism potential in improving the local economy in Merangin. With its unique tourist attraction that is the geological heritage in the form of fossil flora and foliage which integrated with the natural conditions that are still beautiful as well as recreational sports rafting, so if it can be properly managed, will provide great benefit to the local economy. This potential has been seen by the local government, with the implementation of additional business development since 2011. The development is carried out in the form of infrastructure development, increased accessibility and promotion of the development center in Air Batu village. Along with the development of Geopark Merangin region, tourists began to arrive and have increased each year. Although there has been development of the area, but there are still people with low levels of prosperity. This study aims to assess the effect of tourism development for the welfare of society Geopark Merangin Air Batu village. To achieve the objectives of this study, the approach used is positivistic approach with quantitative methods and analysis techniques crosstab.

From this study showed that the development of the area Geopark Merangin during the last 4 years has been an impact on economic conditions Air Batu village. The development of tourism has been able to improve the well-being, so that people who lower their welfare has decreased despite the decline is less significant.
\end{abstract}

Keywords: Merangin Geopark, Tourism, The Level of Prosperity, Air Batu Village

\begin{abstract}
ABSTRAK
Geopark Merangin memiliki potensi wisata yang sangat besar dalam meningkatkan ekonomi masyarakat di Kabupaten Merangin. Dengan keunikan atraksi wisata yang dimilikinya yaitu adanya warisan geologi berupa fosil flora dan dedaunan yang terintegrasi dengan kondisi alam yang masih asri serta rekreasi olahraga arum jeram, sehingga jika hal tersebut dapat dikelola dengan baik akan memberikan manfaat besar bagi ekonomi daerah. Potensi tersebut telah dilihat oleh pemerintah daerah dengan dilakukannya berbagai usaha pengembangan sejak tahun 2011. Adapun pengembangan yang dilaksanakan berupa pengembangan infrastruktur, peningkatan aksesibilitas serta promosi dengan pusat pengembangan di Desa Air Batu. Seiring dengan pengembangan kawasan Geopark Merangin, wisatawan mulai berdatangan dan mengalami peningkatan tiap tahunnya. Meskipun telah ada pengembangan kawasan, tetapi masih terdapat masyarakat dengan tingkat kesejahteraan rendah. Studi ini bertujuan mengkaji pengaruh pengembangan kawasan wisata Geopark Merangin terhadap kesejahteraan masyarakat Desa Air Batu. Untuk mencapai tujuan penelitian ini, pendekatan yang digunakan adalah pendekatan positivistic dengan metode kuantitatif dan teknik analisis crosstab. Dari penelitian ini diperoleh hasil bahwa pengembangan kawasan Geopark Merangin selama 4 tahun terakhir telah memberikan pengaruh pada kondisi ekonomi masyarakat Desa Air Batu. Adanya pengembangan pariwisata telah mampu meningkatkan kesejahteraan, sehingga masyarakat yang kesejahteraannya rendah mengalami penurunan meskipun penurunannya kurang signifikan.
\end{abstract}

Kata Kunci: Kawasan Geopark Merangin, Kepariwisataan, Tingkat Kesejahteraan, Desa Air Batu

\footnotetext{
1 Bappeda Kabupaten Merangin

Kontak penulis: putra_pede@yahoo.co.id

2 Dosen Magister Pembangunan Wilayahdan Kota, Undip Semarang, Jawa Tengah
} 


\section{PENDAHULUAN}

Daerah yang mampu mengoptimalkan potensi salah satu sektor ekonominya akan memiliki tingkat perkembangan yang optimal. Jika dilihat dari keberlanjutannya maka daerah yang pembangunannya tergantung pada sektor perdagangan dan jasa memiliki keberlanjutan dari pada daerah yang pembangunannya tergantung pada eksplorasi sumber daya alam, karena sumber daya alam bersifat limit, jika dieksplorasi dalam jangka panjang potensinya akan habis, berbeda dengan jasa yang tidak akan habis.

Sektor Pariwisata merupakan sektor yang dapat menjadi penopang pertumbahan ekonomi daerah jika dikelola dengan baik dan akan mengurangi ketergantungan daerah pada ekploitasi sumber daya alam. Kenaikan output industri pariwisata gilirannya menyebabkan peningkatan standar hidup pihak yang terlibat didalamnya (Mason, 2003). Pembangunan pariwisata merupakan salah satu pembangunan yang perlu dikembangkan karena dari sektor ini dapat meningkatkan penerimaan devisa negara, menghasilkan pertumbuhan ekonomi yang cepat dalam menyediakan lapangan kerja, peningkatan penghasilan, standar hidup serta menstimulasikan faktor-faktor produksi lainnya (Lickorish, 1994).

Salah satu daerah yang mulai melihat sektor pariwisata sebagai sektor yang menjanjikan untuk perkembangan daerah adalah Kabupaten Merangin. Prospektifnya sektor Pariwisata di Kabupaten Merangin tidak terlepas dengan keberadaan keberadaan warisan geologi (geoheritage) di Desa Air Batu. Pengembangan Geopark mendorong Adanya peningkatan kunjungan wisatawan, dari peningkatan jumlah wisatawan akan meningkatkankan aktivitas ekonomi didalamnya.

Dengan melihat uraian latar belakang bahwa pengembangan sektor pariwisata disuatu daerah akan memberikan pengaruh terhadap perekonomian yang berada di daerah kawasan tersebut, maka perlu dilihat pengaruh pengembangan kawasan wisata Geopark Merangin terhadap kesejahteraan masyarakat desa Air Batu.

\section{METODE PENELITIAN}

Penelitian tentang Pengaruh Pengembangan Kawasan Wisata Geopark Merangin Terhadap Kesejahteraan Masyarakat Desa Air Batu. Dengan adanya aktivitas wisata maka masyarakat akan terkena dampak secara langsung khususnya yang berada di daerah objek wisata. Oleh karena itu dalam penelitian ini akan fokus pada pengaruh pengembangan kawasan wisata terhadap kesejahteraan masyarakat Desa Air Batu. Dengan melihat tujuan tersebut maka pendekatan yang sesuai dengan penelitian adalah pendekatan Positivisme, karena bermaksud melihat keterkaitan antara pengembangan kawasan wisata terhadap kesejahteraan masyarakat dengan metode kuantitatif. Metode penelitian digunakan untuk meneliti pada populasi atau sampel tertentu, pengumpulan data menggunakan instrument penelitian, analisis data yang bersifat kuantitatif/statistik, dengan tujuan untuk menguji hipotesis yang telah ditetapkan (Sugiyono, 2010). Jenis sampling yang dipilih adalah Stratified Sampling dengan jumlah sampel 84 kk. Adapun ketentuan sampel adalah Keluarga yang telah berdomisili di lokasi sebelum dilakukan pengembangan kawasan wisata dan sesudah kawasan wisata geopark dikembangkan.

Penelitian ini mendeskripsikan atau menggambarkan data yang telah terkumpul dengan tujuan untuk menverifikasi atau menguji kebenaran suatu pengetahuan dari penelitian terdahulu pada 
populasi atau sampel tertentu. Analisis data yang digunakan bersifat kuantitatif/statistic dengan tujuan untuk menguji hipotesis yang telah ditetapkan.

\section{GAMBARAN UMUM}

\section{Gambaran Umum Desa Air Batu, Kabupaten Merangin}

Desa Air Batu berada di Kecamatan Renah Pembarap, Kabupaten Merangin Provinsi Jambi. Jarak antara Desa Air Batu dengan Kota Bangko (IbuKota Kabupaten) kurang lebih $30 \mathrm{Km}$ dapat ditempuh dengan selama 30-40 menit dengan kendaraan roda 2 dan roda 4. Secara administrasi Desa Air Batu terdiri dari 4 dusun yaitu Dusun Batu Gajah, Masjid Baru, Liku Harapan dan Air Batu. Kondisi Topografi Desa Air Batu, cenderung perbukitan dibagian selatan desa. Sedangkan dibagian utara dan barat desa agak bergelombang. Topografi datar terdapat di bagian timur desa. Di bagian barat sepanjang Desa Air Batu, dialiri oleh Sungai Merangin.

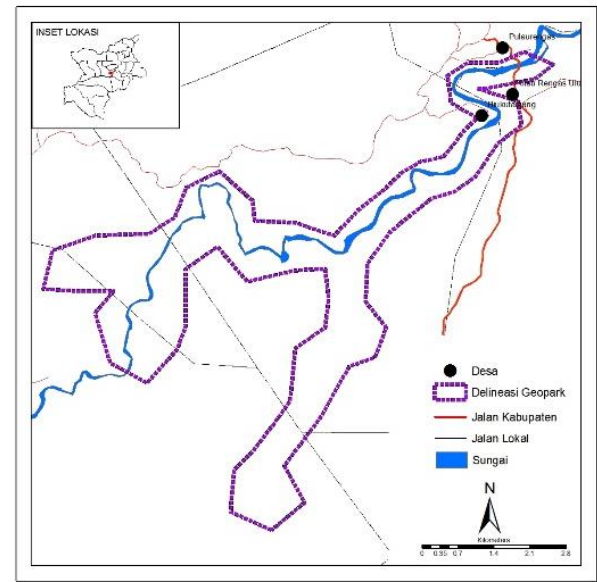

GAMBAR 1. DELINEASI

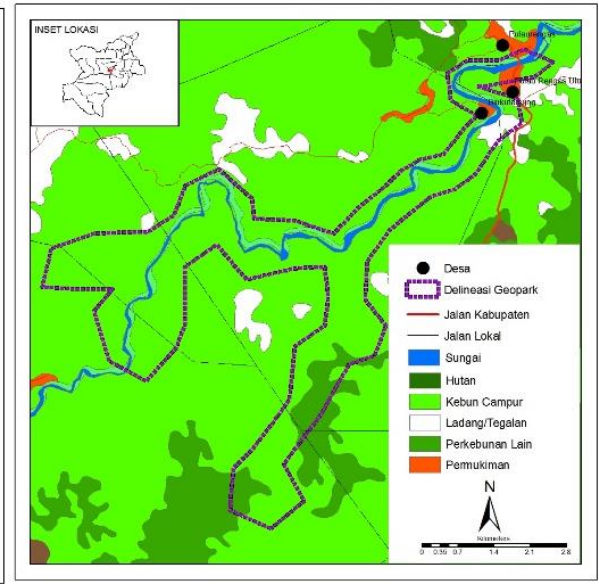

GAMBAR 2. LANDUSE

Pola perkampungan di Desa Air Batu ini adalah memanjang, mengikuti jalan desa. Desa Air Batu dihuni sekitar 2464 orang yang terdiri dari 640 kepala keluarga. Mata pencaharian penduduk Desa Air Batu mayoritas adalah berkebun (98\%), baik itu karet, sawit, duku, durian dan kayu manis. Sisanya, sebesar $2 \%$, bermata pencaharian diluar berkebun, seperti berdagang dan pegawai negeri sipil.

\section{Gambaran Wisata Geopark Merangin}

Keragaman geologi utama di Sungai Merangin yang memiliki nilai Geoheritage adalah fosil flora fauna yang dapat berperan sebagai pendorong untuk membangun sebuah Geopark. Sementara keanekaragaman geologi lainnya seperti fosil kayu, struktur geologi, bentang alam dan lain-lain dapat berperan sebagai pendukung termasuk keanekaragaman biologi maupun budaya setempat. Kawasan Paleobotani Park Merangin merupakan kawasan inti yang seluruhnya berada di Kabupaten Merangin bagian selatan khususnya di bantaran dan aliran Sungai Batang Merangin dan Batang Mengkarang. Fosil-fosil tertua yang ditemukan berusia \pm 300 juta tahun berupa fosil Cordaites, Calamites, Pecoptired, Taeniopteris sp, Gigantopteris sp, Sphenopteris sp dan Araucarioxylon (nama ilmiah latin dari tanam-tanaman). Selain itu kawasan ini juga memiliki beberapa potensi Geodiversity bernilai tinggi untuk dikembangkan menjadi situs warisan geologi. Lokasinya berdekatan dengan beberapa objek goeheritage objek wisata alam seperti goa dan petualangan arum jeram standar internasional. 


\section{STUDI PUSTAKA}

Undang-undang nomor 10 tahun 2009 tentang kepariwisataan mendefinisikan Kepariwisataan adalah keseluruhan kegiatan yang terkait dengan pariwisata dan bersifat multidimensi serta multidisiplin yang muncul sebagai wujud kebutuhan setiap orang dan negara serta interaksi antara wisatawan dan masyarakat setempat, sesama wisatawan, Pemerintah, Pemerintah Daerah, dan pengusaha. Terdapat 4 komponen pembentuk kepariwisataan yaitu industri pariwisata, destinasi wisata, pemasaran dan kelembagaan kepariwisataan. Segala usaha yang dilakukan dalam pengembangan kepariwisataan tujuannya adalah memaksimalkan kunjungan wisatawan atau disebut juga dengan penawaran pariwisata. Medlik, 1991 menyatakan bahwa terdapat 4 komponen dalam penawaran pariwisata yaitu Atraksi (memiliki daya tarik baik daya tarik alam maupun masyarakat dan budayanya), Aksesibel (adanya kemudahan untuk mencapai ke tempat wisata baik wisatawan domestic maupun mancanegara), Fasilitas (pendukung kegiatan wisata seperti hotel, fasilitas umum yang dapat dimanfaatkan wisatawan), Lembaga pariwisata (adanya lembaga pengelolaan wisata sehingga wisata menjadi aman, tentram dan bersih).

Penembangan kawasan wisata didasarkan pada besaran target wisatawan dan asal wisatawan. Berdasarkan asal wisatawan dibedakan menjadi 3 yaitu (i). Wisatawan mancanegara (Wisman), (ii) Wisatawan nasional (Wisnas), (iii) Wisatawan nusantara yaitu wisatawan dalam negeri (domestic tourist) yang dari sisi ekonomi pariwisata dibagi atas dua: (1) Domestic In-BoundTourist, yaitu wisnus yang datang berkunjung ke suatu propinsi lain yang bukan propinsi dimanan biasanya ia tinggal atau menetap. (2) Domestic Out-Bound-Tourist, yaitu wisnus yang melakukan perjalanan wisata ke propinsi lain yang bukan propinsi dimana biasanya ia tinggal atau menetap. Para wisatawan melakukan kunjungan wisata dengan berbagai macam tujuan. Menurut Spillane, 1987 jika dilihat dari motif perjalanan, jenis pariwisata dibagi menjadi 6 jenis yaitu (1) Pariwisata untuk menikmati perjalanan (Pleasure Tourism), (2) Pariwisata untuk rekreasi (Recreation Tourism), (3) Pariwisata untuk kebudayaan (Cultural Tourism), (4) Pariwisata untuk olahraga (Sports Tourism). (5) Pariwisata untuk urusan usaha dagang (Business Tourism). (6) Pariwisata untuk berkonvensi (Convention Tourism). Berdasarkan Peraturan Pemerintah No. 26 tahun 2008 tentang penataan ruang, Geopark termasuk dalam kawasan lindung yaitu kawasan lindung geologi (kawasan cagar alam geologi). Geopark merupakan daerah lindung berdasarkan makna khusus geologi, kelangkaan dan keindahan. Fenomena itu mewakili sejarah, kejadian dan proses bumi. Menurut Komoo,1993 terdapat 4 aspek yang terdapat dalam Geopark sebagai warisan bumi yaitu Aspek ilmiah (sebagai rekaman geologi dan sejarah bumi), Aspek keindahan (unsur-unsur alam yang indah atau tidak umum), Aspek rekreasi (mendukung kegiatan rekreasi alam), Aspek budaya (berkaitan dengan nilai kepercayaan, sejarah, dan arkeologi).

Pengembangan kawasan wisata, termasuk Geopark oleh Pemerintah dan pemerintah daerah dengan harapan memberikan manfaat bagi kondisi sosial ekonomi dan lingkungan masyarakat. Karena menurut Lickorish, 1994 dampak positif lebih besar akan diarasakan jika pengelolaan pariwisata dilakukan dengan baik adalah adanya Kontribusi terhadap pendapatan devisa; Kontribusi pendapatan pemerintah; Penciptaan lapangan kerja; Kontribusi terhadap pembangunan daerah. Pada daerah lokasi pengembangan pariwisata, masyarakat setempat sebagai (host community) akan merasakan dampak secara langsung bagi ekonominya. Peningkatan nilai ekonomi menjadi meningkat (inflasi), elastisitas cenderung lebih tinggi bila substitusi tersedia (Samuelson, 2001). Dampak total pariwisata terhadap ekonomi wilayah merupakan akumulasi langsung dan tidak langsung (Stynes, 1999). Dampak langsung dari pelaksanaan pariwisata adalah: Perubahan jumlah penjualan, Perubahan pendapatan (struktur 
ekonomi), Perubahan pekerjaan dan penerimaan pada usaha, Jumlah pengeluaran. Selain memberikan dampak positif, pengembangan pariwisata juga memberikan dampak negative untuk ekonomi (Mason, 2003) seperti Inflasi, Biaya peluang, ketergantungan berlebihan pada pariwisata.

Pengembangan pariwisata yang memiliki dampak positif dan negative bagi perekonomi muaranya adalah pada tingkat kesejahteraan karena terkait dengan pengeluaran dan pendapatan. Menurut Undang-undang No 11 Tahun 2009 Kesejahteraan Sosial adalah kondisi terpenuhinya kebutuhan material, spiritual, dan sosial warga negara agar dapat hidup layak dan mampu mengembangkan diri, sehingga dapat melaksanakan fungsi sosialnya.

\section{ANALISIS DAN PEMBAHASAN}

Pengembangan kawasan Geopark Merangin di Desa Air Batu yang dilakukan pemerintah dalam beberapa tahun terakhir telah memberikan pengaruh pada kondisi perekonomian di Desa Air Batu. Pengaruh tersebut bersifat positif seperti adanya tambahan sumber mata pencaharian dari sektor pariwisata yang sebelumnya tergantung penuh pada sektor pertanian. Penambahan sumber mata pencaharian tersebut menjadikan pendapatan masyarakat juga meningkat, selain itu juga kawasan menjadi lebih mudah terakses dari pusat kota. Dampak kumulatif dari adanya aktivitas wisata di Desa Air Batu adalah peningkatan kesejahteraan masyarakat, dimana masyarakat dengan tingkat kesejahteraan rendah menjadi berkurang. Tetapi pengaruh tersebut belum signifikan karena masih banyak masyarakat yang tingkat kesejahteraanntya rendah. Belum signifikannya pengaruh pengembangan kawasan wisata Geopark Merangin terhadap kesejahteraan masyarakat Desa Air Batu karena potensi wisata yang ada belum dikelola secara maksimal. Dibawah ini adalah uraian dari temuan studi pengaruh pengembangan kepariwisataan di Desa Air Batu terhadap kesejahteraan masyarakat .

\section{Potensi Pengembangan Kepariwisataan di Desa Air Batu}

Kawasan wisata Geopark adalah wisata yang dikembangkan dengan atraksi utama adalah warisan geologi yang terbentuk dari fosil flora dan fauna. Kawasan geopark dengan fosil flora dan fauna adalah satu-satunya yang ada di Indonesia bahkan didunia sehingga dapat menjadi identitas kawasan wisata Geopark Merangin. Yang akan menjadi daya tarik wisatawan domenstik maupun wisatawan mancanegara. Tetapi Pengembangan atraksi wisata yang dilakukan adalah baru pada mengembangkan olahraga arum jeram yang melintasi bebatuan yang merupakan warisan geologi. Sehingga orang yang berwisata di Geopark umumnya hanya untuk berarum jeram. Untuk itu perlu dilakukan pengembangan berbagai macam atraksi untuk menikmati kawasan geopark tanpa harus berarum jeram. Potensi yang belum dikembangkan adalah atraksi penunjang kawasan Geopark, karena disekitar Geopark banyak terdapat atraksi wisata yang berbeda dengan Geopark Merangin sehingga dapat menjadi alternative wisatawan seperti atraksi wisata alam dan budaya. Dengan banyaknya alternative tujuan wisata, wisatawan menjadi lebih lama di kawasan sehingga terjadi aktivitas ekonomi yang lebih besar yang berimplikasi pada peningkatan kesejahteraan masyarakat, dan meningkatkan PAD terhadap ekonomi daerah.

Dengan terbukannya Bandar udara Muara Bungo menyebabkan ada 2 alternative untuk menjangkau kota Bangko (ibukota Merangin) dengan kondisi jalan yang sudah baik. Potensi aksesibilitas tersebut sudah sangat baik untuk pengembangan Geopark Merangin. Permasalahan yang ada adalah masih sulitnya akses dari Pusat Kota Bangko menuju kawasan wisata dan aksesibilitas didalam kawasan wisata. Aksesibilitas tersebut berupa belum adanya 
ketersediaan moda transportasi umum dari dan ke kawasan wisata dan juga kondisi jalan yang masih belum memenuhi standar. Padahal dengan kondisi jalur aksesibilitas dan moda yang baik akan menjadi pertimbangan wisatawan untuk melakukan wisata, karena selama ini untuk melakukan wisata, wisatawan menyiapkan kendaraan pribadi yang membutuhkan anggaran lebih.

Dari aspek fasilitas, fasilitas Fasilitas penunjang wisata Geopark belum memadai baik fasilitas penunjang dalam objek wisata maupun fasilitas penunjang wisatawan seperti akomodasi. Belum tersedianya fasilitas penunjang membuat kawasan belum menjadi pilihan utama. Untuk itu diperlukan peningkatan fasilitas baik fasilitas penunjang dalam objek wisata maupun fasilitas penunjang wisatawan. Fasilitas penunjang dalam objek wisata dapat dilakukan oleh pemerintah daerah sehingga segala kebutuhan wisatawan dalam melakukan wisata terpenuhi. Dan untuk fasilitas penunjang wisatawan dapat dilakukan oleh masyarakat dan swasta. Untuk disekitar objek wisata dapat dilakukan oleh masyarakat dan untuk yang agak jauh dapat dilakukan oleh swasta dengan kualitas akomodasi yang berstandar baik. karena sasaran wisatawan adalah wisatawan domestik dan mancanegara yang tujuan berwisata adalah untuk rekreasi sehingga membutuhkan fasilitas yang memadai.

Pengelolaan kawasan wisata Geopark Merangin telah dilakukan oleh pemerintah dengan keterlibatan masyarakat. Keterlibatan masyarakat sebagai pelaku dalam pengelolaan kawasan wisata sangat baik sehingga pengembangan memberikan manfaat yang besar bagi masyarakat dan juga menciptakan keberlanjutan dalam pengelolaan. Tetapi pengelolaan yang dilakukan oleh masyarakat belum secara professional untuk itu dibutuhkan peningkatakan kapasitas masyarakat dalam pengelolaan kawasan wisata sehingga potensi yang ada menjadi optimal.

Dengan adanya daya tarik wisatawan baik lokal, domestik maupun mancanegara tentunya demand penyediaan jasa penunjang kepariwisataan akan berkembang seperti akomodasi dan fasilitas penunjang lainnya. Demand tersebut jika dimanfaatkan dengan baik oleh pemerintah, swasta dan masyarakat akan memberikan multiplier effect bagi ekonomi Desa Air Batu khususnya dan umumnya kabupaten Merangin, karena adanya aktivitas ekonomi didalamnya

\section{Perubahan Struktur Ekonomi Masyarakat Desa Air Batu}

Desa Air Batu sebelum ditemukan Geopark yang kemudian dijadikan kawasan pariwisata, sama dengan desa-desa lainnya di Kabupaten Merangin yaitu desa yang sebagian besar bahkan seluruh penduduknya masih tergantung pada mata pencaharian sebagai petani dengan komoditas pertanian adalah karet. Dengan kondisi desa yang masih sulit diakses menuju ke pusat kota, kondisi ekonomi masyarakat sangat rendah karena komoditas hasil pertanian nilai ekonominya menjadi lebih kecil karena akses ke pasar yang rendah.

Dengan menggunakan analisis struktur ekonomi Desa Air Batu sebelum dilakukan pengembangan yaitu pada tahun 2010 dan sesudah dilakukan pengembangan yaitu pada tahun 2014 maka dapat diketahui adanya perubahan struktur ekonomi di Desa Air Batu tanpa adanya perubahan sektor ekonomi basis yang artinya penunjang utama ekonomi desa masih pada sektor pertanian. Adapun perubahan paling utama dalam struktur ekonomi adalah adanya sektor pariwisata sebagai sektor yang berkontribusi pada perekonomi masyarakat Desa Air Batu yang mana pada tahun 2010 sektor pariwisata belum ada kontribusi terhadap perekonomian. Dalam artian bahwa sektor jasa pariwisata telah menjadi alternative mata pencaharian penduduk di Desa Air Batu. 


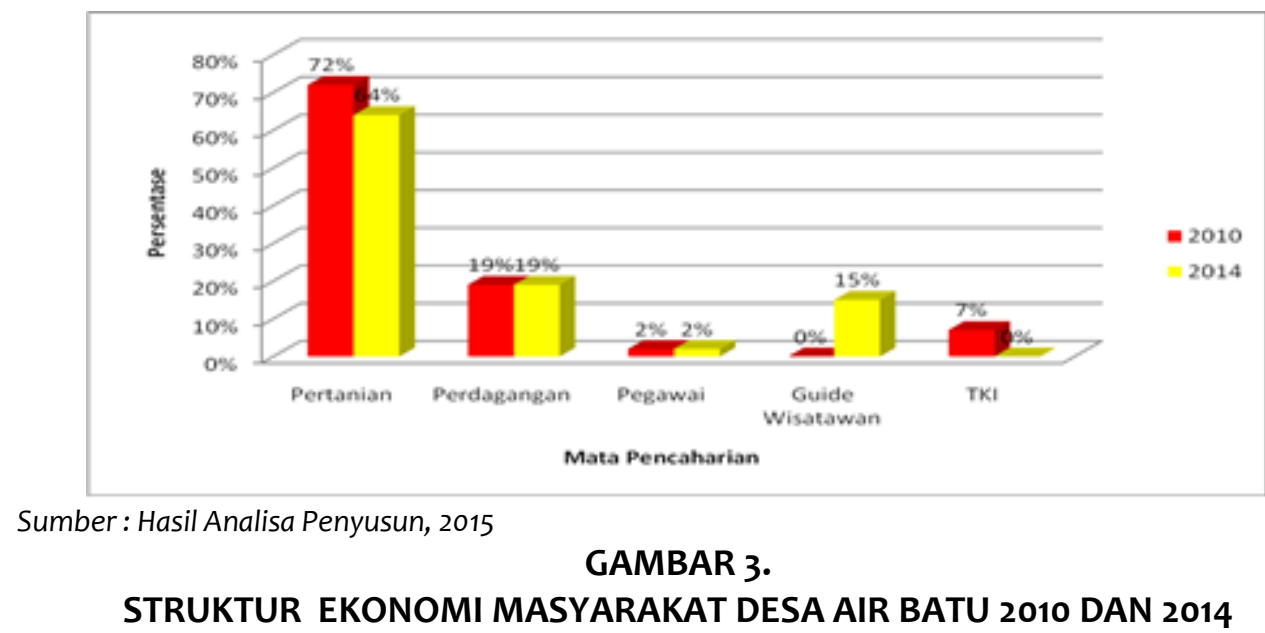

Sektor utama ekonomi di Desa Air Batu adalah sektor pertanian dengan kontribusi $64 \%$ atau mengalami penurunan dibandingkan tahun 2010. Sektor perdagangan, pegawai tidak mengalami perubahan. Masyarakat sebagai Guide Wisatawan pada tahun 2015 sebesar $15 \%$ dan TKI pada tahun 2010 sebesar 7\%, pada tahun 2014 tidak ada. Perubahan paling besar adalah adanya sektor Pariwisata dalam hal ini Guide wisatawan yang dilakukan masyarakat sekitarnya. Sekitar 10 responden petani berprofesi ganda sebagai Guide dan 2 responden petani juga berprofesi ganda sebagai pedagang. Untuk TKI yang pada tahun 2010 bekerja di luar negeri kembali bekerja ke Desa sebagai petani dan juga pedagang. Selain sebagai Penyedian Jasa Guide, sebagai penduduk dapat meningkatkan ekonominya sebagai penyedia jasa akomodasi. Sehingga secara tidak langsung mempengaruhi ekonomi Desa. Hal ini terlihat dari 12 responden yang berprofesi sebagai petani menjadikan rumahnya sebagai Homestay, 3 responden sebagai pedagang dan 2 sebagai pegawai juga sebagai penyedia akomodasi.

Kegiatan pariwisata Geopark Merangin di Desa Air Batu telah mengubah struktur ekonomi (mata Pencaharian Penduduk), karena sektor pariwisata sebelum dilakukan pengembangan tidak memberikan sumbangsih pada penyerapana tenaga kerja (pembentuk ekonomi). Tetapi setelah dilakukan pengembangan sektor pariwisata telah berkontribusi pada perekonomian desa terlihat dengan besarnya penduduk yang sekarang mengantungkan hidupnya dari aktivitas wisata, meskipun beberapa penduduk menjadikan aktivitas wisata sebagai tambahan penghasilan meskpin aktivitas pariwisata belum merubah sektor ekonomi basis di Desa Air Batu. Aktivitas pariwisata di Desa Air Batu yang baru berjalan selama 4 tahun telah memberikan kontribusi pada perubahan struktur ekonomi penduduk desa dari yang tergantung sepenuhnya pada pertanian menjadi sebagian tergantung pada sektor pariwisata. Dengan semakin besarnya pengaruh pariwisata terhadap perekonomian penduduk maka sudah sepatuhnya mengembangan Geopark lebih di intesifkan sehingga memberikan dampak yang positif pada perekonomian desa pada umumnya dan khususnya masyarakat. Karena mengembangan kepariwisataan akan memberikan multiplier effect pada kondisi sosial ekonomi masyarakat yang berada di kawasan wisata dan kabupaten pada umumnya khususnya dalam penyerapan Tenaga kerja yang akan berimplikasi pada peningkatan kesejahteraan.

\section{Perubahan Kesejahteraan Masyarakat Desa Air Batu}

Tingkat kesejahteraan dibedakan dalam 3 kelompok yaitu masyarakat dengan kesejahteraan tinggi, masyarakat dengan kesejahteraan sedang dan masyarakat dengan kesejahteraan rendah. Untuk Paramater tiap indikator pendapatan dan pengeluaran menggunakan pendapatan 
tertinggi dan terendah kemudian dibagi kedalam ketiga interval, untuk pendidikan dan kondisi rumah. Dibawah ini adalah parameter dari masing-masing indikator:

TABEL 1. INDIKATOR PENILAIAN TINGKAT KESEJAHTERAAN

\begin{tabular}{|c|c|c|}
\hline Indikator Tingkat Kesejahteraan & Parameter & Skor \\
\hline \multirow{3}{*}{$\begin{array}{l}\text { Tingkat pendapatan/penghasilan keluarga: diukur } \\
\text { dari besarnya pendapatan keluarga perkapita } \\
\text { dalam sebulan yang dibagi menjadi tiga kategori } \\
\text { dengan interval yang sama dalam satuan rupiah. }\end{array}$} & Rp. 722.225 - Rp. 1.000 .000 & 3 \\
\hline & Rp. 444.446 - Rp. 722.224 & 2 \\
\hline & Rp. 166.667-Rp. 444.445 & 1 \\
\hline \multirow{3}{*}{$\begin{array}{l}\text { Tingkat konsumsi/pengeluaran keluarga: diukur dari } \\
\text { besarnya pengeluaran keluarga perkapita dalam } \\
\text { sebulan yang dibagi menjadi tiga kategori dengan } \\
\text { interval yang sama dalam satuan rupiah. }\end{array}$} & Rp. 273,811-Rp. 375000 & 3 \\
\hline & Rp. $172.620-$ Rp. 273,810 & 2 \\
\hline & Rp. 71,429 - Rp. 172,619 & 1 \\
\hline \multirow[t]{3}{*}{ Pendidikan keluarga: } & $\begin{array}{l}>60 \% \text { jumlah anggota } \\
\text { keluarga tamat SD; }\end{array}$ & 3 \\
\hline & $\begin{array}{l}\text { 30-60\% jumlah anggota } \\
\text { keluarga tamat SD; }\end{array}$ & 2 \\
\hline & $\begin{array}{l}<30 \% \text { jumlah anggota } \\
\text { keluarga tamat SD; }\end{array}$ & 1 \\
\hline \multirow[t]{3}{*}{ Kondisi Rumah } & Permanen & 3 \\
\hline & Semi-Permanen & 2 \\
\hline & Non Permanen & 1 \\
\hline
\end{tabular}

Dengan menggunakan skor tertinggi dan terendah kemudian dibagi kedalam 3 interval, didapatkan hasil sebagai berikut: Tingkat kesejahteraan tinggi (9.4-12), Tingkat kesejahteraan sedang (skor 6.7-9.3), Tingkat kesejahteraan rendah (skor 4.6.6).

Berdasarkan hasil penelitian didapatkan bahwa terjadi trend peningkatan masyarakat dengan kesejahteraan rendah menjadi masyarakat dengan kesejahteraan sedang. Dan Peningkatan masyarakat berpendapatan sedang menjadi masyarakat peningkatan tinggi masih sangat kecil.

Dengan menggunakan hasil analisa perhitungan tingkat kesejahteraan di Desa Air Batu dengan menggunakan 4 kriteria yaitu pendapatan, pengeluaran, pendidikan dan juga kondisi rumah, maka dapat dilihat perubahan tingkat kesejahteraan dari tahun 2010 (sebelum dilakukan pengembangan kawasan pariwisata Geopark Merangin) dan tahun 2014 (sesudah dilakukan pengembangan kawasan wisata Geopark Merangin) didapatkan hasil bahwa terjadi pergeseran tingkat kesejahteraan (terjadi peningkatan tingkat kesejahteraan masyarakat).

Pada tahun 2010 masyarakat dengan tingkat kesejahteraan tinggi sebesar 4\% dan pada tahun 2014 terjadi peningkatan 200\% menjadi sebesar 12\% masyarakat di Desa Air Batu memiliki tingkat kesejahteraan Tinggi. Untuk masyarakat dengan tingkat kesejahteraan sedang pada tahun 2010 sebesar $57 \%$ dan naik menjadi $71 \%$ pada tahun 2014 . Dan untuk masyarakat berpenghasilan rendah mengalami penurunan dari 39\% pada tahun 2010 menjadi sebesar 17\% pada tahun 2014 .

Peningkatan penduduk yang mengalami peningkatan kesejahteraan ke tingkat sedang dipengaruhi oleh pendapatan yang meningkat. Disisi lain walaupun terjadi peningkatan pada pengeluaran tetapi peningkatan lebih kecil dibandingkan dengan peningkatan pendapatan. Sehingga secara ekonomi surplus pendapatan masyarakat lebih tinggi pada tahun 2014 dibandingkan tahun 2010. Dengan adanya peningkatan pendapatan dan mobilitas barang khususnya bahan bangunan membuat adanya peningkatan kualitas rumah masyarakat yang 
sebelum rumah non permanen menjadi semi permanen dan permanen, untuk rumah semi permanen menjadi rumah permanen.

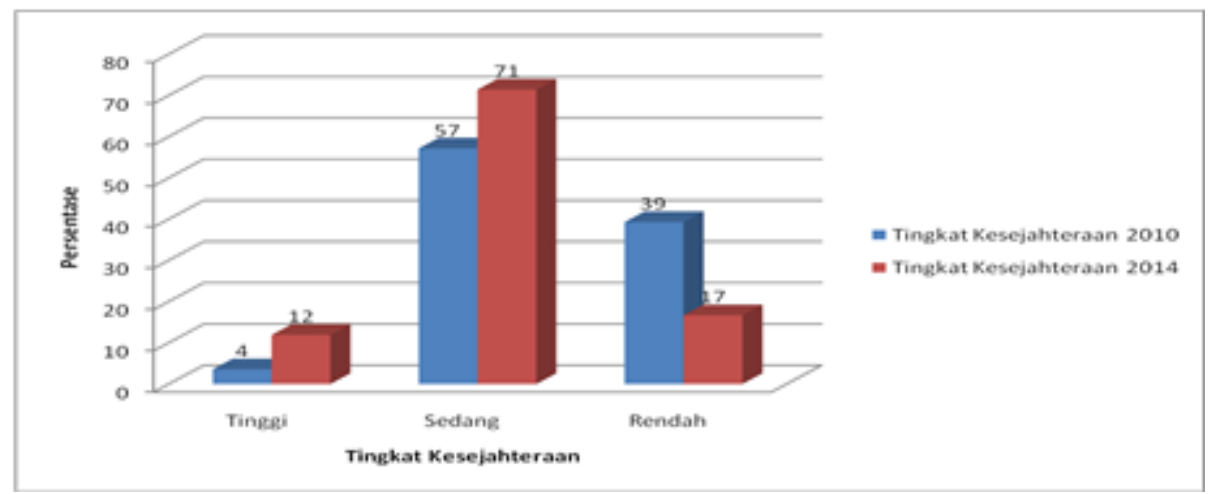

Sumber : Hasil Analisa Penyusun, 2015

GAMBAR 4.

TINGKAT KESEJAHTERAAN MASYARAKAT DESA AIR BATU 2010 DAN 2014

Peningkatan pendapatan penduduk Desa Air Batu dari tahun 2010 ke 2014 disebabkan adanya aktivitas wisata di Geopark Merangin sehingga penduduk memiliki penghasilan tambahan berupa penyediaan jasa akomodasi, penyediaan jasa Guide wisatawan dan juga penyedian barang untuk keperluan wisatawan (perdagangan) dan dapat juga disebabkan peningkatan harga komoditas pertanian masyarakat karena adanya akses yang baik ke pasar.

\section{Pengaruh Pengembangan Pariwisita Terhadap Kesejahteraan}

Berdasarkan hasil analisa hubungan tiap variabel dengan tingkat kesejahteraan masyarakat Desa Air Batu kawasan pengembangan wisata Geopark Merangin didapatkan hasil sebagai berikut :

TABEL 2. CROSSTAB VARIABEL PENGEMBANGAN WISATA DENGAN KESEJAHTERAAN

\begin{tabular}{|c|c|c|c|c|}
\hline Variabel & $\begin{array}{l}\text { Nilai Asymp. } \\
\text { Sig. }\end{array}$ & Keterangan Keterkaitan & $\begin{array}{c}\text { Korelasi } \\
\text { Phi }\end{array}$ & $\begin{array}{l}\text { Tingkat } \\
\text { Korelasi }\end{array}$ \\
\hline $\begin{array}{l}\text { Keterlibatan } \\
\text { Masyarakat }\end{array}$ & 0.016 & $\begin{array}{l}\text { Ada hubungan dengan } \\
\text { tingkat kesejahteraan }\end{array}$ & 0.313 & Rendah \\
\hline HAMPA & 0.826 & $\begin{array}{l}\text { Tidak Ada hubungan dengan } \\
\text { tingkat kesejahteraan }\end{array}$ & 0.068 & \\
\hline Kepemilikan Aset & 0.002 & $\begin{array}{l}\text { Ada hubungan dengan } \\
\text { tingkat kesejahteraan }\end{array}$ & 0.492 & Tinggi \\
\hline Umur & 0.837 & $\begin{array}{l}\text { Tidak Ada hubungan dengan } \\
\text { tingkat kesejahteraan }\end{array}$ & 0.182 & \\
\hline $\begin{array}{l}\text { Pekerjaan } \\
\text { Masyarakat }\end{array}$ & 0.000 & $\begin{array}{l}\text { Ada hubungan dengan } \\
\text { tingkat kesejahteraan }\end{array}$ & 0.564 & Tinggi \\
\hline $\begin{array}{l}\text { Jarak Rumah ke } \\
\text { objek wisata }\end{array}$ & 0.191 & $\begin{array}{l}\text { Tidak Ada hubungan dengan } \\
\text { tingkat kesejahteraan }\end{array}$ & 0.322 & \\
\hline Frekuensi Mobilitas & 0.002 & $\begin{array}{l}\text { Ada hubungan dengan } \\
\text { tingkat kesejahteraan }\end{array}$ & 0.536 & Tinggi \\
\hline
\end{tabular}

Sumber : Hasil analisis penyusun, 2015 
Dari seluruh variabel tersebut yang terkait dengan kepariwisataan adalah: keterlibatan masyarakat, kepemilikan aset, pekerjaan masyarakat, dan frekuensi mobilitas. Pembukaan kawasan wisata Geopark Merangin di Desa Air Batu membuat sebagian masyarakat terlibat dalam penyediaan jasa untuk para wisatawan baik secara langsung maupun tidak langsung sehingga dibandingkan tahun sebelum pengembangan ada peningkatan penghasilan masyarakat, sehingga meningkatkan tingkat kesejahteraan masyarakat. Tingkat keterkaitan antara keterlibatan masyarakat dalam wisata dengan tingkat kesejahteraan masih rendah karena keterlibatan masyarakat dalam aktivitas wisata masih rendah sehingga pendapatan masyarakat dalam keterlibatan dalam aktivitas wisata masih kecil kontribusinya Dengan adanya pengembangan kawasan wisata Geopark Merangin, menyebabkan masyarakat yang sebelum hanya memilki aset berupa kebun, menjadi memiliki jasa akomodasi wisata seperti cottege dan warung/toko untuk kebutuhan wisatawan sehingga masyarakat memiliki sumber pendapatan yang meningkatkan tingkat kesejahteraan. Keterkaitan antara tingkat kesejahteraan dengan kepemilikan aset tinggi, yang berarti semakin besar aset kebun yang dimiliki maka semakin tinggi kesejahteraan dan keberadaa aset yang terkait dengan jasa wisata juga mampu meningkatkan kesejahteraan masyarakat. pengembangan kawasan wisata juga menyebabkan masyarakat memilkialternatif pekerjaan yaitu sebagai penyedia jasa untuk wisatawan baik sebagai pekerjaan utama maupun sebagai pekerjaan sampingan. Dengan adanya pekerjaan dibidang pariwisata membuat masyarakat mendapatkan peningkatan pendapatan sehingga tingkat kesejahteraan menjadi tinggi. Tingkat keterkaitan antara pekerjaan masyarakat dalam wisata dengan tingkat kesejahteraan tinggi. Semakin banyak jenis pekerjaan dan semakin terlibat dalam kegiatan wisatwa kesejahteraan masyarakat semakin meningkat karena masyarakat mendapatkan sumber pendapatan tambahan

Pembukaan kawasan wisata membutuhkan aksesibilitas menuju objek wisata yaitu berupa jalan yang baik. dengan kondisi jalan yang baik mobilitas masyarakat meningkat, harga komoditas masyarakat menjadi lebih tinggi karena biaya transportasi yang murah, biaya barang menjadi lebih murah, akses terhadap fasilitas pendidikan menjadi lebih mudah dan bahan bangunan untuk meningkatkan kualitas rumah menjadi lebih murah, dengan seluruh manfaat dari adanya aksesibilitas menuju objek wisata, maka pengembangan kawasan wisata mampu memberikan peningkat tingkat kesejahteraan masyarakat. Keterkaitan antara tingkat kesejahteraan dengan frekuensi mobilitas tinggi. Yang artinya semakin tinggi mobilitas akan menyebabkan semakin tinggi tingkat ksejahteraan

Pengembangan pariwisata di Desa Air Batu terhadap kesejahteraan dapat dilihat dari adanya keterlibatan masyarakat dalam aktivitas wisata, adanya perubahan kepemilkan aset dari tidak ada aset terkait wisata menjadi ada aset terkait wisata, terjadinya perubahan pekerjaan masyarakat dari pertanian menjadi penyedia jasa pemandu wisata dan terjadinya peningkatan frekuensi mobilitas. Perubahan-perubahan tersebut mempengaruhi kesejahteraan masyarakat. 


\section{KESIMPULAN DAN REKOMENDASI}

Berdasarkan hasil penelitian pengaruh pengembangan kawasan Geopark Merangin terhadap kesejahetraan masyarakat Desa Air Batu di Kabupaten Merangin didapatkan kesimpulan sebagai berikut:

- Wisata Geopark Merangin Sangat Potensi Sebagai Destinasi Wisata Prioritas Tetapi Belum Dikelola Secara Maksimal

Potensi Geopark Merangin sebagai destinasi prioritas wisatawan tersebut dikelola/dikembangkan secara maksimal. Kurangnya pemahaman wisatawan terhadap potensi lain yang dimiliki kawasan Geopark Merangin disebabkan masih kurangnya sosialisasi dan publikasi yang dilakukan oleh pemerintah. Selain permasalahan publikasi yang masih minim, masih terbatasnya fasilitas penunjang membuat wisatawan tidak menjadikan Geopark sebagai destinasi wisata prioritas, keterbatasan fasilitas baik yang berada di dalam objek wisata maupun fasilitas akomodasi. Fasilitas akomodasi yang ada masih sangat sederhana sehingga belum mampu memberikan kenyaman wisatawan. Potensi terakhir yang belum dimanfaatkan secara maksimal dalam pengembangan wisata Geopark adalah modal sosial (masyarakat). Masyarakat yang mendukung penuh pengembangan wisata belum mendapatkan peningkatan kapasitas dalam pengelolaan atraksi wisata, sehingga pengelolaan yang dilakukan belum professional.

- Pengembangan Kawasan Wisata Geopark Merangin Telah Merubah Struktur Ekonomi Masyarakat

Pengembangan Geopark Merangin di Desa Air Batu telah merubah struktur ekonomi masyarakat. Masyarakat yang sebelumnya pengembangan tergantung sepenuhnya pada sektor pertanian sebagai sumber mata pencaharian, setelah pengembangan yaitu pada tahun 2014 terjadi pergeseran mata pencaharian, sebagian petani bekerja di sektor jasa pariwisata sehingga sektor jasa pariwisata menjadi sektor kedua pembentuk ekonomi Desa Air Batu. Meskipun ada perubahan struktur ekonomi di Desa Air Batu tetapi hal tesebut belum mampu berubah sektor utama/primer. Sektor primer di Desa Air Batu masih sektor pertanian. Sektor pariwisata belum menjadi sektor utama/primer karena pengembangan yang dilakukan baru beberapa tahun dan aktivitas wisata belum terlalu besar sehingga hanya sebagian kecil masyarakat yang mata pencaharian di sektor penyediaan jasa wisata.

- Pengembangan kawasan wisata Geopark Merangin telah mampu meningkatkan kesejahteraan masyarakat

Terjadinya pergeseran tingkat kesejahteraan masyarakat Desa Air Batu menjadi lebih baik dengan semakin banyaknya masyarakat yang tingkat kesejahteraanya tinggi dan sedang dan berkurangnya masyarakat dengan tingkat kesejahteraan rendah dibandingkan tahun 2010 sebelum dilakukan pengembangan kawasan. Dengan adanya aktivitas wisata di Desa Air Batu, terjadi peningkatan pendapatan masyarakat. Peningkatan pendapatan masyarakat umumnya terjadi karena masyarakat terlibat langsung dalam pengelolaan kawasan wisata sehingga masyarakat mendapatkan imbalan jasa dalam penyediaan jasa wisata baik sebagai pemandu maupun sebagai penyedian akomodasi. Ada juga beberapa masyarakat yang tidak terlibat dalam aktivitas wisata tetapi menerima peningkatan pendapatan dari usaha perdagangan. Usaha 
perdagangan yang semakin baik khususnya pada pemenuhan kebutuhan wisatawan yang datang membuat masyarakat mendapatkan keuntungan lebih. Adanya pengembangan wisata akan diiringi peningkatan aksesibilitas menuju objek wisata. Dengan aksesibilitas yang baik tersebut selain memudahkan bagi wisatawan juga memberikan keuntungan bagi masyarakat karena harga komoditas pertanian menjadi lebih baik dengan adanya akses pasar dan biaya transportasi yang murah. Sehingga dengan adanya aksesibilitas membuat pendapatan meningkat dan pengeluaran menjadi lebih kecil yang berarti kesejahteraan menjadi meningkat.

Kecilnya pengaruh pengembangan wisata Geopark Merangin terhadap kesejahteraan masyarakat karena pengembangan yang dilakukan belum optimal. Pengoptimalan pengaruh pengembangan kawasan wisata Geopark Merangin dalam meningkatkan kesejahteraan masyarakat dapat dilakukan dengan cara Peningkatan penawaran wisata Geopark Merangin dilakukan secara komprehensif yaitu melalui peningkatkan atraksi dari kualitas dan kuantitas sehingga wisatawan memiliki alternative dalam berwisata, peningkatan aksesibilitas kawasan baik dari prasarana transportasi maupun dari sarananya; (i) Peningkatan infrastruktur kepawisataan baik didalam objek wisata maupun diluar objek wisata yang menunjang aktivitas wisata serta meningkatkan promosi dan sosialisasi tentang wisata Geopark Merangin; (ii) peningkatan kapasitas masyarakat dalam pengelolaan kawasan wisata, akan membuat masyarakat mendapatkan manfaat yang lebih besar lagi dengan adanya aktivitas wisata. Selain manfaat bagi masyarakat, keterlibatan masyarakat dalam pengelolaan wisata akan membuat objek wisata menjadi berkelanjutan karena adanya konservasi ekologi yang dilakukan secara langsung oleh masyarakat (ada rasa memiliki dari masyarakat yang membuat mereka menjaga aset wisata yang ada karena dari aset tersebut kesejahteraan masyarakat menjadi meningkat); (iii) keterlibatan yang intensif dari pemerintah dalam mengembang kawasan wisata. Keterlibatan pemerintah tentunya dalam kebijakan dan juga penyediaan infrastruktur. Pelibatan swasta juga dibutuhkan dalam pengembangan kawasan wisata baik untuk penyediaan akomodasi maupun melakukan promosi secara langsung kepada calon wisatawan.

\section{DAFTAR PUSTAKA}

Koomo, Ibrahim. 1993. Conservation Geology: Protecting Hidden Treasures of Malaysia, ASM Inaugural Lectures, LESTARI, University Kebangsaan Malaysia.

Lickorish, Leonard J et al, 1994, Developing Tourism Destination : Policies and Perspective, Longman Group, UK.

Mason, Peter. 2003. Tourism Impact, Planning and Management. Burlington: ButterworthHeinemann.

Medlik, S. 1991. Managing Tourism, London: Butterworth-Heinemann Ltd.

Peraturan Pemerintah No. 26 tahun 2008. Tentang Rencana Tata Ruang Wilayah Nasional.

Samuelson, Paul A. 2001. Makro-Ekonomi, Edisi Keempat belas Jakarta: Erlangga.

Spillane J. J. 1987, Pariwisata Indonesia Sejarah dan Prospeknya. Yogyakarta: Kanisius.

Stynes, Daniel, J. 1999. "Economic Impacts of Tourism". Di akses tanggal 23 februari 2015melalui ttps://www.msu.edu/course/prr/840/econimpact/pdf/ecimpvol1.pdf

Sugiyono. 2010. Metode Penelitian Kuantitatif Kualitatif \& RND. Bandung: Alfabeta.

Undang-Undang Republik Indonesia No. 10 tahun 2009 Tentang Kepariwisataan.

Undang-Undang Republik Indonesia No. 11 tahun 2009 Tentang Kesejahteraan Sosial. 